\section{DIARY}

Modern treatment options for periodontal disease with Dr lan Peace (webinar) Date: 13 December 2012 Telephone: 08000723313 www.dentsply.co.uk

The therapeutic gradient, a medical concept for actual dentistry? by Dr Jean Pierre Attal Date: 29 January 2013 Venue: BDA, London Email: I.greenwall@btconnect.com www.ao.org

'Wearing away' by Prof. David Bartlett Date: 12 February 2013 Venue: BDA, London Email: I.greenwall@btconnect.com www.ao.org

Alpha Omega dental fraternity Jerusalem Conference Date: 7-11 March 2013 Email: I.greenwall@btconnect.com

British Dental Conference

ct Exhibition 2013

Date: 25-27 April 2013

Venue: ExCel London www.bda.org/conference

ADI Team Congress Date: 1-3 May 2013 Venue: Manchester Central Convention Complex www.adi.org.uk/congress2013
LAURA IS YOUNG DENTAL WRITER OF THE YEAR

Laura Hatton, formerly of the Dental Tribune, was awarded first place in the British Dental Editors' Forum (BDEF) Young Dental Writer of the Year awards which was held at the British Dental Association (BDA) in September.

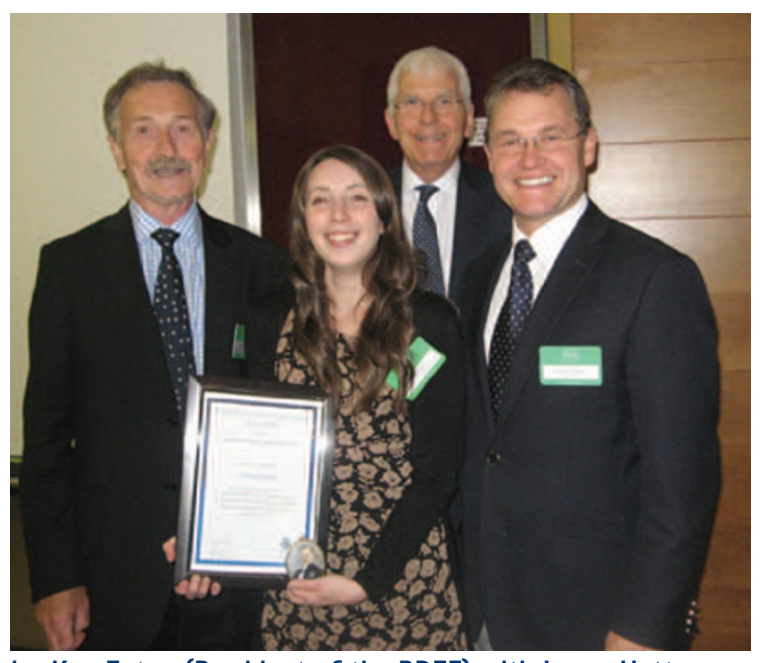

I-r Ken Eaton (President of the BDEF) with Laura Hatton (Dental Tribune) and Tony Reed and Simon Tucker (BDTA)
Ms Hatton took first place with her three-part article The truth from the trenches, exploring the role of dentist Sir Harry Baldwin during World War I. The piece was commended by judges for its meticulous research and vivid account of horrific facial injuries suffered by thousands of soldiers fighting in France.

Alexander Holden, a foundation dentist at Stag Dental Care in Rotherham, was awarded second place with his BDJ article Lost in transition - changes in communication in the leap from dental student to foundation dentist (BDJ 2011; 211: 459-461).

The two award winners were presented with cheques and certificates by Simon Tucker, president of the British Dental Trade Association (BDTA), who sponsor the Young Dental Writer awards.

\title{
FIRST PORTAL OF CALL FOR PRIMARY CARE DENTISTS
}

A new dental portal from NHS

Dental Services for NHS dental providers and performers working in primary care is now live.

For the first time, dentists will have 24/7 secure access to both contractual information and information on the processing of their NHS activity via the new portal.

Once users have activated their account they will be able to use the portal to check their latest activity figures, and view and download their monthly pay statements the moment they are produced.

www.nhsbsa.nhs.uk/DentalServices/portal

\section{HONOURS, AWARDS, APPOINTMENTS}

\section{Young Endodontist Award}

First place in the Young Dentist Endodontic Award 2012 was awarded to Rahul Bose, an associate in Oxford and London. Second place went to Luis Fernandez Escarabajal and joint third place went to Michael Taylor and Thomas Hickley. Between them they won $£ 3,500$ of prizes at a party to celebrate the 10th anniversary of the Harley Street Centre for Endodontics in October.

\section{ILM Level 7 Diploma}

London dentist Martin Delahaye is the first dentist to achieve the Institute of Leadership and Management's Level 7 Diploma in Strategic Leadership and Executive Management. He joins an elite group of management professionals and has been invited to become a Fellow of the ILM.

\section{BDA BULLETIN}

- Maple Dental Care Ltd, in the Brooklands area of Manchester, has been named BDA Good Practice Scheme Practice of the Year. The practice were due to receive their award at the BDA Honours and Awards Dinner taking place on 21 November.

- The BDA says that the Department of Health must act immediately to avert the possibility of UK dentistry graduates being denied foundation training places again in 2013. The warning follows an announcement that the number of applicants invited to take place in the applications process exceeds the estimated number of available training places by almost 200 . Thirty-five applicants were not allocated places this year.

- There are five days left to enter a ballot to attend the 2012 BDA Christmas Lecture. Professor Alastair Sloan will address the subject of Regenerative dentistry and stem cells; current thoughts and research on the evening of 13 December 2012. BDA members can apply for a free ticket by sending an email to xmaslecture@bda.org stating their name, BDA number, postal address and telephone number. The draw for tickets will take place on 29 November. 